\title{
PHILOSOPHY
}

\section{Formation existentialist beliefs of V. Stus}

\author{
Y. Kotets \\ Vasyl Stus Donetsk National University \\ Corresponding author. E-mail: kostenkoyana1992@gmail.com \\ Paper received 13.02.21; Accepted for publication 25.02.21.
}

\section{https://doi.org/10.31174/SEND-HS2021-249IX44-10}

\begin{abstract}
The reasons for V. Stus's appeal to the philosophy of existentialism, psychological and historical conditions for writing existential works are studied; the intellectual phenomenon of the writer in the Ukrainian literature is considered. The article considers the way of V. Stus to build his own version existentialism.
\end{abstract}

Keywords: Existentialism, existence, the problem of choice, inner experience.

Introductions. Vasyl Stus is a genius artist and a profound intellectual who has become a symbol of the nation in our time. Today, critics evaluate the creative legacy of V. Stus ambiguously. Some researchers claim that the poet's work is no longer relevant today. Western critics believe that Stus is a representative of our culture and emphasize the value of his work and the artist's individuality. Vasyl Stus recreated the most notable features of his time based on world poetry and the philosophy of existentialism. Stus's work is permeated with existential and symbolic content. In my opinion, Stusiv's existentialism is special, in which a person always opposes the outside world, while preserving national roots.

Aims. Consider the formation and structuring of existentialist beliefs of V. Stus. Manifestations of existential motives are characterized by the example of the collections of the poet-philosopher Stus «Winter Trees» and «Palimpsests».

Materials and methods. The choice of research methods is due to the peculiarities of scientific issues and the theoretical issues that are solved in the work, based on a combination of several methodological strategies. The research

uses a synthesis of such scientific methods: cultural-historical - comprehension of creativity of the poet through the prism of cultural-historical experience; biographical an appeal to fragments of a writer biography for the interpretation of his work with elements of psychological analysis; comparative typological - the identification and analysis of typological ascents, not caused by direct contacts;

Brief overview of related publications. Theoretical and methodological basis are both philosophical , cultural studies and literary works of Ukrainian and foreign researchers: M. Bakhtin , M. Buber, O. Potebni, B. Tomashevsky, V. Proppa , A. Lord K. Levi - Strauss , Ts. Todorova V. Soloviev, M. Berdyaev, G. - G. Gadamer, M. Heidegger, M. Blanche, X. Ortega- i- Gasset, E. Levinas , P. Rickera , O. Gaxley, J. Zhenetta, O. Zholkovsky , Natalia Fateeva, Natalia Pege- Gro, D. Nalyvaika, G. Grabovicha , T. Gavriliva , Yu. Kovaliv, as well as scientific studios of Mikhailina Kotsyubinskaya, Yu. Shevelev, L. Plyushch, D. Stus, Myroslava Gnatyuk, Olena Rosinskaya, K. Moskalets and others like that.

Results. The philosophical component of poetry is an important component in understanding the work of Stus, because in order to comprehend it should be as close as possible to the state in which the poet lived and worked. However, the poet's work is not fully explored, a large number of opinions about it are not said. The constructive perception of Stus's poetry in his homeland did not come immediately, as did the publication of his books. Printing began with magazines and newspapers. In April 1989, two selections of poems appeared - in the magazine "Flag" with an accompanying word on a few lines by Ivan Drach and in the newspaper "Youth of Ukraine" with the same, approximately, anonymous preface. For the most part, it was about the fate of the poet and his civic face

Modern philosophical and literary explorations of the work of W. Stus, the memoirs of his contemporary friends show that the poet was seriously interested in the theories of leading existentialist philosophers, especially A. Camus, J. P. Sartre, K. Jaspers, M. Heidegger.

Stus became acquainted with European philosophers mainly through quotations, not books. In particular, in a letter to his wife dated July 5, 1976, he wrote that "certain quotations close the door - and for the sake of these particularities, a book was read" [8, p. 57]. His son Dmytro Stus would later say, after analyzing his father's philosophical considerations, that this fragmentary reading "did not yet make it possible to form a clear idea of existentialism as a philosophical trend."

But, instead, it allowed anyone interested in supplementing the doctrine with individually close ideas about what it should be "[8, p. 58]. As you know, the journal of the Union Academy of Sciences" Questions of Philosophy "was subscribed to the place of imprisonment of the poet Apparently, one of the readers was Vasyl Stus himself, and there is so-called material evidence that the poet was interested in the philosophy of existentialists, such as: available among the manuscript heritage notes from the works of Ortega y Gasset and requests in a letter of exile to Anna Gali Gorbach helped with the acquisition of works by Jaspers, Heidegger.

As for Sartre's existentialism, V. Stus did not accept the non-recognition of God, as well as the materialist interpretation of existence. Closer to Stus was the rebellion of A. Camus, which required the denial of all forms of slavery and ideologies that oppress the individual, any social utopias. Even his own search for the existential meaning of life V. Stus began with doubts that were inherent in the thoughts of A. Camus, leaning against the rebellion against the absurdity of existence and awareness of the need to 
overcome the strip of inter-being as a transitional stage and between profane and sacred worlds.

We can see that often the lyrical heroes of Stus's poems, when faced with difficult trials and deliberately not avoiding them, he, endowed with human qualities, left alone with his own conscience, is sometimes permeated with feelings of uncertainty and hesitation: to plead with God? " [6, p. 30].

Yu. Bedryk was one of the first to point out existentialism in the work of Vasyl Stus and ways to comprehend this philosophy. In his work "Vasily Stus: The problem of perception" the researcher gives the key to understanding the worldview of the poet [1, p. 25].

M. Kotsyubynska considers philosophy of existentialism of Stus's work in the aspect of "philosophy of life", due to its emergence by the crisis of the rationalist thinking of the second half of the XIX century. and awareness of limitation logocentric systems that claimed absolute knowledge and ignored irrational phenomena.

Researcher Petro Kraliuk believes that: "Stus's existentialism is no worse than the existentialism of Albert Camus or Jean-Paul Sartre. It is only necessary to subtract it "[3, p. 8].

Yuri Shevelyov wrote about Stus's existential motives: "In the philosophy of existentialism, as is well known, the idea of man's abandonment of the world did not exclude human activity, on the contrary, it rather demanded it. And in Stus. The consciousness of its mission elevates it beyond the circumstances of biography, beyond all circumstances of life and geographical affiliation ... "[1, p. 75].

Manifestations of existential motives, we can clearly see in the collections "Winter Trees" and "Palimpsests". In them, the poet appears with his own philosophy of evaluation of human existence, as well as with his own established worldview, which the researcher M. Kotsyubynska considers in the aspect of "philosophy of life."

It is worth noting that the title of the collection "Winter Trees" is symbolic and with a certain subtext. This is a kind of sign of loneliness. In the preface to the collection, Stus writes that "A poet is a person. First of all. And a man is first of all a gentleman!" [6, p. 42].

Apparently, it was because of his isolation from the world and his confinement by prison walls that the poet, a man aware of the danger of disorientation in time and space limited by prison realities, was forced to find a way of existential trials at this difficult time. Vasyl Stus highlights a number of existential problems in these collections. One of them is the experience of the national essence. It should be noted that the philosophical motives of Stus are not characterized by patriotic sublimity. On the contrary, it is characterized by national self-criticism and sometimes even acceptance of Ukraine's troubles.

Howl like a beast, drink vodka ...

and the day to substitute the sleeping faithful subject, and do not rumble on the breed,

when your Haydamat family

cut with lines for lunch

several crazy years [7, p. 118]

Under the influence of the circumstances of that time, Stus increasingly heard notes of pessimism and hopelessness:

What will happen tomorrow? God will give the day and the bread.
And what if there is no day?

Then already - death, since then already death, walking to death at random [7, p. 312].

All the motives in the previous works are sharpened in "Palimpsests". Stus's poetry is full of ups and downs, joy and sorrow, despair and forgiveness.

For example, Mykola Ilnytsky described the collection in such words as "This state of" liberation "from the circumstances, the environment. This state of loneliness is the path of the greatest openness to the whole world and to the hearts of people... ».

Yevhen Sverstiuk would later write: "Those poems cannot be flipped through - they must be entered and slowly lived, as the poet lived in the stages of his chambers - and then a unique page of poetry of the twentieth century opens - the age of alienation. [5, p. 8].

V. Didkivsky compares Stus with Rilke and points out that Rilke's sonnets are, perhaps, the forerunners of "Palimpsests" "[4, p. 8].

Palimpsests are characterized by a wealth of images, such as God, pain, death, which are an integral part of the artist's poetry. They are also filled with motives such as hated love for Ukraine, the desire to return to the homeland and at the same time curse it.

In order to fully comprehend the philosophical component of Stus's works, it is necessary, in my opinion, to get as close as possible to the state in which the poet was writing at the time. It should be noted that despite the closeness between Stus and existential philosophy, it should be noted the differences due to historical factors - primarily the importance of the national factor for the environment of spiritual culture to which the poet belonged.

His existential choice is somewhat reminiscent of the guidelines of A. Camus and J.-P. Sartre, recognizing the equivalence of human capabilities. V. Stus was acquainted with the atheistic existentialism of J.-P. Sartre, but the poet did not accept that Sartre does not acknowledge God and interprets existence from a materialist point of view.

The famous Sixties Ivan Dziuba was convinced that: "Philosophers of existentialism, who repeatedly turned to poetry to confirm their views погляд would find the richest material in the work of Stus. But he also has, in my opinion, a certain denial or overcoming of the existential worldview. It is that the main antinomies and problems of existentialism (life - death, existence as a being to death, loneliness - communication; fear - determination; abandonment of being - the realization of freedom; existence impersonal) the poet opens in experiencing the fate of his people and belonging. to him, in a feat for him "[2, p. 15].

Conclusions. Thus, analyzing and revealing the specifics and nature of the philosophy of Vasyl Stus, we can say that the work of Stus is deeply imbued with existentialsymbolic content.

There are two main areas of activity of Stus - poetry based on philosophy and philosophy based on poetry. I believe that the philosophy of Stus, as well as his predecessors - existentialists $\neg \neg$ - is primarily a non-academic philosophy. In the poet's work we can distinguish the fundamental principles and problems of existentialism, namely: the problem of existence, the problem of choice, the problem of the thinking "I", the problem of the difference between man and the world.

Today, Vasyl Stus is one of the classics of Ukrainian 
poetry and a fighter for statehod. He wanted us to feel like real, not declared masters in our country, and the Ukrainian language and culture will reach its heyday.

\section{ЛИТЕРАТУРА}

1. Бедрик Ю. Василь Стус: Проблема сприймання. - К.: ПБП “Фотовідеосервіс", 1993. - 80 с.

2. Дзюба І. Свіча у кам'яній пітьмі // Стус В. Палімпсест: Вибране. - К., 2003. - С.15

домінанта// „Слово і час”, № 12, 1999

5. Сверстюк С. На святі надій. Василь Стус - летюча зірка української літератури// „Слово і час”, № 6, 1998

3. Кралюк, П. Василь Стус як європеєць / Петро Кралюк // День. 2013. - 5-6 квіт. - С. 8 .

4. Рарицький О. Палімпсести Василя Стуса - духовна

6. Стус В. Твори у 4-х т., 6-ти кн. - Львів, 1994;

7. Стус В. Твори: У 6 т., 9 кн. - Львів: Просвіта, $1994-1999$.

8. Стус як текст. - Мельбурн, 1992

\section{REFERENCES}

1. Bedryk Y. Vasyl Stus: The problem of perception. - K .: PBP "Photovideoservice", 1993. - $80 \mathrm{p}$.

2. Dziuba I. Candle in the stone darkness // Stus V. Palimpsest: Favorites. - K., 2003. - P.15

"Word and Time", № 12, 1999

3. Kraliuk, P. Vasyl Stus as a European / Petro Kraliuk // Day. 2013. - April 5-6. - P. 8.

5. Sverstyuk E. On the feast of hopes. Vasyl Stus is a flying star of Ukrainian literature // "Word and Time", № 6, 1998

6. Stus V. Works in 4 volumes, 6 books. - Lviv, 1994;

7. Stus V. Works: In 6 vols., 9 books. - Lviv: Prosvita, 1994 1999.

4. Rarytsky O. Palimpsests of Vasyl Stus - spiritual dominant // $\quad$ 8. Stus as text. - Melbourne, 1992 